\title{
Evaluation of Antibacterial and Antifungal Activity of Chitosan in Integument of Cockroaches
}

\author{
Hadi Shahraki ${ }^{1}, 2$, Hamid Reza Basseri ${ }^{1}$, Hadi Mirahmadii ${ }^{2,3^{*}}$, Mehdi Fatahi Bafghi ${ }^{4}$, Ahmad Mehravarn ${ }^{2,3}$, Peyman \\ Heydarian $^{5}$, Bahman Rahimi Esboei ${ }^{6}$
}

'Department of Medical Entomology, School of Public Health, Tehran University of Medical Sciences, Tehran, Iran ${ }^{2}$ Infectious Diseases and Tropical Medicine Research Center, Zahedan University of Medical Sciences, Zahedan, Iran ${ }^{3}$ Department of Parasitology, Mycology, and Entomology, Faculty of Medicine, Zahedan University of Medical Sciences, Zahedan, Iran

${ }^{4}$ Department of Medical Bacteriology, School of Public Health, Tehran University of Medical Sciences, Tehran, Iran ${ }^{5}$ Department of Medical Parasitology, School of Medicine, Qazvin University of Medical Sciences, Qazvin, Iran

${ }^{6}$ Department of Parasitology and Mycology, School of Public Health, Tehran University of Medical Sciences, Tehran, Iran

\author{
*Correspondence to \\ Hadi Mirahmadi, \\ Tel: +98-09149664568 \\ Email: hmirahmadi59@gmail.com
}

Received January 28, 2017 AcceptedMarch 7, 2017 Published online September 30, 2018

\begin{abstract}
Introduction: Due to drug resistance and toxic side effects observed following administration of many antibacterial drugs, novel strategies are highly needed for treatment of bacterial diseases. Chitosan, as an important immune system stimulator, is found in cockroaches that are living in contaminated sites. The aim of this study was to extract the chitosan from nymph and adult stage of both Blattella germanica and Periplaneta americana and to evaluate its antibacterial and antifungal activities.

Methods: The mature form of $B$. germanica and the nymph and adult forms of $P$. americana were killed by $\mathrm{CO} 2$ gas, and washed and dried at $60^{\circ} \mathrm{C}$. Then, they were mechanically ground in a mixer and passed through 20 mesh size. Finally, chitosan was extracted from shrimp processing discards. Chitosan was dissolved in lactic acid $1 \%$ and its effects against Staphylococcus aureus, Escherichia coli, Pseudomonas aeruginosa, Vibrio cholerae, methicillin-resistant S. aureus, Candida albicans, and Aspergillus were evaluated.

Results: Chitosan extracted from cockroaches showed antibacterial effects on gram-positive bacteria especially $S$. aureus and $E$. coli. However, it had no impact on fungi.

Conclusion: The findings of the current study revealed that chitosan had excellent antibacterial activities.

Keywords: Chitosan, Antifungal, Antibacterial, Insects
\end{abstract}

\begin{abstract}
Introduction
Since a vast majority of bacterial species developed resistance against antibacterial drugs which are highly toxic, novel strategies are required to be employed in this respect. The annual cost of drugresistant infections is estimated to be $\$ 20$ billion in surplus health care costs and 8 million extra hospital days in the United States. ${ }^{1}$ Because the majority of insects such as cockroaches live in contaminated areas, they appear to have developed effective strategies to deal with pathogens. ${ }^{2}$ Chitosan as a natural polysaccharide has been widely used in pharmaceutical excipients. ${ }^{3}$ This material is produced by the deacetylation of chitin. Chitin is a natural polymer composed of randomly dispersed $\beta$-(1-4)-
\end{abstract}

linked D-glucosamine. This biopolymer is a major component of not only organisms like crustaceans, fungi, and insects, ${ }^{4}$ but also of invertebrates' integument. ${ }^{5}$ Chitin can also be produced by chemical and biological methods. ${ }^{6,7}$ Chitin annual turnover was estimated to range from $10^{10}$ to $10^{11}$ tones. ${ }^{8,9}$ Additionally, it can be readily obtained by simple extraction. ${ }^{6}$ In addition, it contains proteins, minerals, lipids, and pigments. ${ }^{10}$ Chitosan has characteristic features such as bioadhesive nature and hydrophilic properties. Besides, it can be used as potent carrier for braintargeted drugs, transdermal films and wound healing biodegradable grafts, as well as antimicrobial and stabilizing constituent of liposomes. Due to these properties,

(C) 2018 The Author(s); Published by Zabol University of Medical Sciences. This is an open-access article distributed under the terms of the Creative Commons Attribution License (http://creativecommons.org/licenses/by/4.0), which permits unrestricted use, distribution, and reproduction in any medium, provided the original work is properly cited. 
chitosan, as one of the most promising renewable polymeric materials for a variety of applications, has received greater attention than before. According to some studies, the unique capabilities of chitosan have made it a strong pharmaceutical option. ${ }^{11-13}$ Notably, it facilitates the transportation of polar drugs through the epithelial surfaces and is regarded as both biocompatible and biodegradable. ${ }^{14}$

Recently, various studies have focused on the strong antimicrobial effects of chitosan against different groups of microorganisms, from bacteria ${ }^{15}$ to fungi, ${ }^{16}$ parasites, ${ }^{17-20}$ and yeasts. ${ }^{21}$ Therefore, investigations on the chitosan and its antimicrobial potential have recently become of particular interest. ${ }^{22-26}$ Despite numerous studies on the antimicrobial effects of chitosan, researchers have not yet come up with a consensus result in this respect. Therefore, further studies should be conducted accordingly.

The major commercial sources of chitin and chitosan come from wastes of marine food production and also crab and shrimp shells. ${ }^{27-30}$ Moreover, this material can be produced from exoskeleton of arthropods as well as the cell walls of fungi and yeasts. ${ }^{5}$ Insects like Periplaneta americana and Blattella germanica are the potential sources of chitosan due to their high reproduction rate. ${ }^{31}$ Because of the low content of minerals and total protein in insects' body, less acidic and alkaline materials are required to extract the chitin and chitosan. ${ }^{32}$ According to what has previously been mentioned, this study aimed at extracting chitin and chitosan from nymph and adult cuticle of cockroaches (B. germanica \& P. americana) and assessing the anti-bacterial and anti-fungal properties of the extracted chitosan.

\section{Materials and Methods}

Preparation of Insect Corpses

In this study, the nymph and adult forms of B. germanica and $P$. americana were obtained from the Laboratory of Medical Entomology, Tehran University of Medical Sciences. Adult and nymph forms were killed by $\mathrm{CO} 2$ gas. Subsequently, insect corpses were washed by distilled water (DW) and dried at $60^{\circ} \mathrm{C}$. Then, they were mechanically crushed in a mixer and passed through 20 mesh size.

\section{Demineralization}

Chitosan was extracted from shrimp processing discards using a method described by Chang et $\mathrm{al}^{27}$ Demineralization step was accomplished by mixing $5 \mathrm{~g}$ of $B$. germanica and $P$. americana integument dry powder with $1 \mathrm{M} \mathrm{HCl}$ at $100^{\circ} \mathrm{C}$ for 30 minutes followed by rinsing with $\mathrm{DW}$ until natural $\mathrm{pH}$ was obtained. This demineralized insect sample was subsequently washed (with 99\% ethanol) and air dried at room temperature.

\section{Deproteinization}

This step was performed using alkaline treatment. The de- mineralized integuments dry powder was deproteinized with $1 \mathrm{M} \mathrm{NaOH}$ solution at $80^{\circ} \mathrm{C}$. This step was repeated several times during 24 hours. The chitin product was filtered through $20 \mu \mathrm{M}$ mesh and washed with DW until the $\mathrm{pH}$ became neutral.

\section{Deacetylation}

In order to deacetylate the chitin, $\mathrm{NaOH} 50 \%$ was used at $100^{\circ} \mathrm{C}$ for 4 hours. Then, the alkali was drained off and washed thoroughly with DW until the $\mathrm{pH}$ was less than 7.5 and subsequently dried at ambient temperature $\left(30 \pm 2^{\circ} \mathrm{C}\right)$.

\section{Antimicrobial Susceptibility Test}

The suspensions of bacteria were prepared in sterile phosphate-buffered saline (PBS) and standardized to $1 \times$ $10^{6} \mathrm{CFU} / \mathrm{mL}$. The antimicrobial activities of the chitosan solution were tested against Staphylococcus aureus (ATCC; 25923), Escherichia coli (ATCC 25922), Pseudomonas aeruginosa (ATCC 27853), Vibrio cholerae (ATCC; 39315), and methicillin-resistant S. aureus (ATCC: 33591) by disk diffusion method (Bauer et al, 1996). Bacterial suspension was initially prepared and inoculated onto the entire surface of a Mueller-Hinton agar (MHA) (diameter, $90 \mathrm{~mm}$ ) with $\mathrm{pH}$ of 6.9 using a sterile cotton-tipped swab to form an even lawn.

The plate was air-dried for 15 minutes and five sterile paper disks $(6 \mathrm{~mm}$ in diameter; $\mathrm{BD}$, Becton Dickinson Diagnostic Systems) impregnated with 20 $\mu \mathrm{L}$ diluted chitosan solution $(0.4 \%$ \& $0.8 \%$ for chitosan concentration, respectively) were loaded on the surface of each MHA plate using a sterile pair of forceps. Then, the plates were incubated aerobically at $37^{\circ} \mathrm{C}$ for 24 hours. The diameter of inhibition zone was measured after 24 hours of incubation in the usual manner.

\section{Disc Diffusion Method for Fungi}

Disk diffusion method was performed for fungi against Candida albicans and Aspergillus species on yeast nitrogen base glucose detection (YNBG). Five disks papers, impregnated with chitosan solution, were placed over the MHA medium.

\section{Data Analysis}

All steps of this work were carried out in triplicate. Data were analyzed using SPSS (statistical package for the social sciences) software, version 18. In addition, ANOVA and independent student $t$ test were used.

\section{Results}

Demineralization

Five grams of the yielded powder of integument from $B$. germanica and $P$. americana were treated with $1 \mathrm{M}$ $\mathrm{HCl}$ in order to extract the chitin (Table 1). The average of the remaining material were 2.12 and $2.17 \mathrm{mg}$ after demineralization step for nymph and adult forms of $B$. 
Table 1. The Integument Composition of Blattella germanica and Periplaneta americana

\begin{tabular}{llllll}
\hline Species Names & Stage & Chitosan Composition (\%) & Chitin Composition (\%) & Mineral Composition (\%) & Protein Composition (\%) \\
\hline \multirow{2}{*}{ B. germanica } & Nymph & 5 & 5.6 & 42.4 & 52 \\
& Adult & 5.2 & 6.2 & 43.4 & 44 \\
\multirow{2}{*}{ P. americana } & Nymph & 3.6 & 4.4 & 42.6 & 53 \\
& Adult & 11 & 14.8 & 46.6 & 38.6 \\
\hline
\end{tabular}

germanica while being 2.13 and $2.33 \mathrm{mg}$ for nymph and adult forms of $P$. americana.

\section{Deproteinization}

The average amounts of the remaining chitin after deproteinization from $B$. germanica in nymph and adult forms were 0.28 and $0.31 \mathrm{mg}$ whereas in P. americana, nymph adult forms, they were 0.22 and $0.74 \mathrm{mg}$, respectively.

\section{Deacetylation}

Following deacetylation of B. germanica and P. americana, to extract the chitosan in $\mathrm{NaOH} 50 \%$, the average amounts of the remaining chitosan were 0.25 and $0.26 \mathrm{mg}$ in nymph and adult forms of B. germanica and also 0.18 and $0.55 \mathrm{mg}$ in nymph and adult forms of $P$. americana, respectively.

Antibacterial Test

In this test, both gram-positive and gram-negative bacteria were tested. The chitosan showed different degrees of antibacterial activity against $S$. aureus, E. coli, and $P$. aeruginosa. However, no significant antibacterial activity was observed against $V$. cholerae and methicillinresistant S. aureus. Table 2 shows inhibition zone for different concentrations of chitosan against the tested bacteria. The chitosan did not show any activity against C. albicans and Aspergillus species.

\section{Discussion}

Chitin is a major part of the insect's cuticle, which always covalently binds to minerals and proteins. The most

Table 2. Inhibition Zone Diameter $(\mathrm{mm})$ Following Administration of Different Concentrations of Chitosan for Selected Bacteria

\begin{tabular}{|c|c|c|c|c|}
\hline & Species & Developmental Stage & $\begin{array}{c}\text { Diameter Inhibition Zone } \\
(\mathrm{mm}) 500 \mu \mathrm{g} / \mathrm{mL}\end{array}$ & $\begin{array}{c}\text { Diameter Inhibition Zone } \\
(\mathrm{mm}) 1 \mathrm{mg} / \mathrm{mL}\end{array}$ \\
\hline \multirow[t]{6}{*}{ S. aureus } & B. germanica & Nymph & $<0.5^{*}$ & 12 \\
\hline & & Adult & $<0.5^{*}$ & 11.5 \\
\hline & P. Americana & Nymph & $<0.5^{*}$ & 11.2 \\
\hline & & Adult & $<0.5^{*}$ & 11 \\
\hline & Chitosan $^{* *}($ Standard $)$ & & $<0.5^{*}$ & 10.5 \\
\hline & Control (lactic acid 1\%) & & $<0.5^{*}$ & 10.6 \\
\hline \multirow{6}{*}{$\begin{array}{l}\text { Pseudomonas } \\
\text { species }\end{array}$} & B. germanica & Nymph & $<0.5^{*}$ & 11.2 \\
\hline & & Adult & $<0.5^{*}$ & 10.4 \\
\hline & P. Americana & Nymph & $<0.5^{*}$ & 9.6 \\
\hline & & Adult & $<0.5^{*}$ & 8.8 \\
\hline & Chitosan (standard) & & 10.5 & 11.2 \\
\hline & Control (lactic acid 1\%) & & $<0.5^{*}$ & $<0.5^{*}$ \\
\hline \multirow[t]{6}{*}{ E. coli } & B. germanica & Nymph & $<0.5^{*}$ & 10.4 \\
\hline & & Adult & $<0.5^{*}$ & 9.6 \\
\hline & P. americana & Nymph & $<0.5^{*}$ & $<0.5^{*}$ \\
\hline & & Adult & $<0.5^{*}$ & 9.3 \\
\hline & Chitosan (standard) & & $<0.5^{*}$ & 10 \\
\hline & Control (lactic acid 1\%) & & $<0.5^{*}$ & $<0.5^{*}$ \\
\hline \multirow[t]{6}{*}{ V. cholera } & B. germanica & Nymph & $<0.5^{*}$ & $<0.5^{*}$ \\
\hline & & Adult & $<0.5^{*}$ & $<0.5^{*}$ \\
\hline & P. Americana & Nymph & $<0.5^{*}$ & $<0.5^{*}$ \\
\hline & & Adult & $<0.5^{*}$ & $<0.5^{*}$ \\
\hline & Chitosan (standard) & & $<0.5^{*}$ & $<0.5^{*}$ \\
\hline & Control (lactic acid 1\%) & & $<0.5^{*}$ & $<0.5^{*}$ \\
\hline \multirow{6}{*}{$\begin{array}{l}\text { Methicillin- resistant } \\
\text { S. aureus }\end{array}$} & B. germanica & Nymph & $<0.5^{*}$ & $<0.5^{*}$ \\
\hline & & Adult & $<0.5^{*}$ & $<0.5^{*}$ \\
\hline & P. americana & Nymph & $<0.5^{*}$ & $<0.5^{*}$ \\
\hline & & Adult & $<0.5^{*}$ & $<0.5^{*}$ \\
\hline & Chitosan (standard) & & $<0.5^{*}$ & $<0.5^{*}$ \\
\hline & Control (lactic acid 1\%) & & $<0.5^{*}$ & $<0.5^{*}$ \\
\hline
\end{tabular}


frequently used method for chitin extraction from insects has two steps: 1) an acidic step, to eliminate minerals (also named demineralization step); and 2) a basic step, to eliminate the proteins from cuticle (also referred to as deproteinization step). ${ }^{4}$

In this study, the amount of chitosan extracted from adults and nymphs of the two spices was completely different. Compared to the results obtained in previous studies on crab and shrimp shells, ${ }^{27}$ based on the percentage of the obtained compounds, these results suggest that the methods used for chitosan production from crab and shrimp shells was also an effective method for chitosan extraction from adult and nymph forms of $P$. americana and B. germanica as well.

There are various studies focused on the antimicrobial activity of different chitosans and their derivatives from different sources. The results of all these studies proved that chitosan inhibited the development of a wide variety of bacteria..$^{25,33-36}$ In fact, different concentrations of both types of chitosan used in the present study demonstrated antimicrobial activity on the selected bacteria. ${ }^{37}$ However, chitosan could not inhibit the development of methicillin-resistant $S$. aureus species. Applying chitosan in cooperation with $\mathrm{Ag}+$ nanoparticles has rendered antibacterial activities. ${ }^{38}$ In fact, the use of nanoscale compounds because of the availability to the drug target, could increase its effect. There are some examples in this regard..$^{20,39}$

Preliminary studies demonstrated that chitosan extracted from $P$. americana was more effective than what extracted from $B$. germanica ${ }^{40}$ while in the current experiment, the chitosan extracted from B. germanica showed better level of efficacy. Furthermore, chitosan was shown to have better effects on gram-positive than on gram-negative bacteria.

In general, there has been little research on antifungal activity of chitosan. Kendra et al assessed the antifungal effects of different acetylation grade of chitosan against Fusarium solani in an in vitro study. The results indicated that chitosan had maximum antifungal activity especially the high-molecular-weight chitosan. ${ }^{41}$ In the current study, no inhibitory activity of chitosan was observed in fungi. Chitosan was found to have a greater antifungal activity at $\mathrm{pH}=4.0 .^{42}$ However, in order to be passed through the anti-bacterial filter, chitosan solution was prepared at $\mathrm{pH}=7.0$. It is worth to mention that this solution is extremely dense at $\mathrm{pH}=4.0$ and will not pass through the anti-bacterial filter.

\section{Conclusion}

According to the results of the recent study, chitosan had antimicrobial effects. For this reason, it is expected that further studies to be carried out on this compound to determine its antibacterial or antimicrobial effects on other bacteria and microorganisms. Additional studies should also be undertaken to determine the toxic effects of this combination in order to eventually introduce it as an antimicrobial agent.

\section{Ethical Approval}

Considering that human and animal samples were not used in this study, there was no need for moral confirmation.

\section{Competing Interests}

The authors declare that there is not any conflict of interests.

\section{Acknowledgments}

This work was conducted in Department of Medical Entomology. The authors would like to thank the Department of Medical Microbiology and Medical Mycology of Tehran University of Medical Sciences.

\section{References}

1. Fair RJ, Tor Y. Antibiotics and bacterial resistance in the 21st century. Perspect Medicin Chem. 2014;6:25-64. doi:10.4137/pmc.s14459

2. Otvos L Jr. Antibacterial peptides isolated from insects. J Pept Sci. 2000;6(10):497-511. doi:10.1002/10991387(200010)6:10<497::aid-psc277>3.0.co;2-w

3. Struszczyk H, Pospieszny H, Gamzazade AI. Chitin and chitosan. Polish-Russian monograph. 2002(1).

4. Goodrich JD, Winter WT. a-Chitin nanocrystals prepared from shrimp shells and their specific surface area measurement. Biomacromolecules. 2007;8(1):252-257. doi:10.1021/bm0603589

5. Einbu A, Naess SN, Elgsaeter A, Varum KM. Solution properties of chitin in alkali. Biomacromolecules. 2004;5(5):2048-2054. doi:10.1021/bm049710d

6. Kjartansson GT, Zivanovic S, Kristbergsson K, Weiss J. Sonication-assisted extraction of chitin from North Atlantic shrimps (Pandalus borealis). J Agric Food Chem. 2006;54(16):5894-5902. doi:10.1021/jf060646w

7. Sorlier P, Denuziere A, Viton C, Domard A. Relation between the degree of acetylation and the electrostatic properties of chitin and chitosan. Biomacromolecules. 2001;2(3):765-772.

8. Gooday GW, Prosser JI, Hillman K, Cross MG. Mineralization of chitin in an estuarine sediment: the importance of the chitosan pathway. Biochem Syst Ecol. 1991;19(5):395-400. doi:10.1016/0305-1978(91)90056-6

9. Gopalan Nair K, Dufresne A. Crab shell chitin whisker reinforced natural rubber nanocomposites. 2. Mechanical behavior. Biomacromolecules. 2003;4(3):666-674. doi:10.1021/bm0201284

10. Percot A, Viton C, Domard A. Optimization of chitin extraction from shrimp shells. Biomacromolecules. 2003;4(1):12-18. doi:10.1021/bm025602k

11. Lehr C-M, Bouwstra JA, Schacht EH, Junginger HE. In vitro evaluation of mucoadhesive properties of chitosan and some other natural polymers. Int J Pharm. 1992;78(13):43-48. doi:10.1016/0378-5173(92)90353-4

12. Muzzarelli RA. Chitin enzymology. Paper presented at: International Symposium on Chitin Enzymology 1996: Senigallia, Italy; 1996. 
13. Yen MT, Yang JH, Mau JL. Physicochemical characterization of chitin and chitosan from crab shells. Carbohydr Polym. 2009;75(1):15-21. doi:10.1016/j.carbpol.2008.06.006

14. Cho YI, No HK, Meyers SP. Physicochemical characteristics and functional properties of various commercial chitin and chitosan products. J Agric Food Chem. 1998;46(9):38393843. doi:10.1021/jf971047f

15. Yadollahi M, Farhoudian S, Namazi H. One-pot synthesis of antibacterial chitosan/silver bio-nanocomposite hydrogel beads as drug delivery systems. Int J Biol Macromol. 2015;79:37-43. doi:10.1016/j.ijbiomac.2015.04.032

16. Liu W, Qin Y, Liu S, Li P. C-coordinated chitosan metal complexes: design, synthesis and antifungal properties. World Acad Sci Eng Technol, International Journal of Agricultural and Biosystems Engineering. 2017;11(12):182.

17. Rahimi-Esboei B, Fakhar M, Chabra A, Hosseini M. In vitro treatments of Echinococcus granulosus with fungal chitosan, as a novel biomolecule. Asian Pac J Trop Biomed. 2013;3(10):811-815. doi:10.1016/s2221-1691(13)60160-4

18. Fakhar M, Chabra A, Rahimi-Esboei B, Rezaei F. In vitro protoscolicidal effects of fungal chitosan isolated from Penicillium waksmanii and Penicillium citrinum. J Parasit Dis. 2015;39(2):162-167. doi:10.1007/s12639-013-0300-y

19. Yarahmadi M, Fakhar M, Ebrahimzadeh MA, Chabra A, Rahimi-Esboei B. The anti-giardial effectiveness of fungal and commercial chitosan against Giardia intestinalis cysts in vitro. J Parasit Dis. 2016;40(1):75-80. doi:10.1007/ s12639-014-0449-z

20. Rahimi MT, Ahmadpour E, Rahimi Esboei B, et al. Scolicidal activity of biosynthesized silver nanoparticles against Echinococcus granulosus protoscolices. Int J Surg. 2015;19:128-133. doi:10.1016/j.ijsu.2015.05.043

21. Grisin T, Bories C, Bombardi M, et al. Supramolecular chitosan micro-platelets synergistically enhance antiCandida albicans activity of amphotericin B using an immunocompetent murine model. Pharm Res. 2017;34(5):1067-1082. doi:10.1007/s11095-017-2117-3

22. Jeon YJ, Kamil JY, Shahidi F. Chitosan as an edible invisible film for quality preservation of herring and atlantic cod. J Agric Food Chem. 2002;50(18):5167-5178.

23. Rabea EI, Badawy ME, Stevens CV, Smagghe G, Steurbaut W. Chitosan as antimicrobial agent: applications and mode of action. Biomacromolecules. 2003;4(6):1457-1465. doi:10.1021/bm034130m

24. Tikhonov VE, Stepnova EA, Babak VG, et al. Bactericidal and antifungal activities of a low molecular weight chitosan and its $\mathrm{N}$-/2(3)-(dodec-2-enyl)succinoyl/-derivatives. Carbohydr Polym. 2006;64(1):66-72. doi:10.1016/j. carbpol.2005.10.021

25. Tsai GJ, Zhang SL, Shieh PL. Antimicrobial activity of a low-molecular-weight chitosan obtained from cellulase digestion of chitosan. J Food Prot. 2004;67(2):396-398.

26. Zheng LY, Zhu JF. Study on antimicrobial activity of chitosan with different molecular weights. Carbohydr Polym. 2003;54(4):527-530. doi:10.1016/j.carbpol.2003.07.009

27. Chang KLB, Tsai G, Lee J, Fu W-R. Heterogeneous $\mathrm{N}$-deacetylation of chitin in alkaline solution. Carbohydr Res. 1997;303(3):327-332. doi:10.1016/S00086215(97)00179-1

28. Mojarrad JS, Nemati M, Valizadeh H, Ansarin M, Bourbour S. Preparation of glucosamine from exoskeleton of shrimp and predicting production yield by response surface methodology. J Agric Food Chem. 2007;55(6):2246-2250. doi:10.1021/jf062983a

29. Wang X, Xing B. Importance of structural makeup of biopolymers for organic contaminant sorption. Environ Sci Technol. 2007;41(10):3559-3565.

30. Xu Y, Gallert C, Winter J. Chitin purification from shrimp wastes by microbial deproteination and decalcification. Appl Microbiol Biotechnol. 2008;79(4):687-697. doi:10.1007/s00253-008-1471-9

31. Wall R, Shearer D. Veterinary entomology: arthropod ectoparasites of veterinary importance. Springer Science \& Business Media; 1997.

32. Oduor-Odeto PM, Struszezyk MH, Peter MG. Characterisation of chitosan from blowfly larvae and some crustacean species from Kenyan marine waters prepared under different conditions. Western Indian Ocean J Mar Sci. 2005;4(1):99-107.

33. Jeon YJ, Park PJ, Kim SK. Antimicrobial effect of chitooligosaccharides produced by bioreactor. Carbohydr Polym. 2001;44(1):71-76. doi:10.1016/S01448617(00)00200-9

34. No HK, Kim SH, Lee SH, Park NY, Prinyawiwatkul W. Stability and antibacterial activity of chitosan solutions affected by storage temperature and time. Carbohydr Polym. 2006;65(2):174-178. doi:10.1016/j. carbpol.2005.12.036

35. No HK, Meyers SP. Preparation and characterization of chitin and chitosan-a review. J Aquat Food Prod Tech. 1995;4:27-52.

36. Yang TC, Chou CC, Li CF. Antibacterial activity of $\mathrm{N}$-alkylated disaccharide chitosan derivatives. Int J Food Microbiol. 2005;97(3):237-245. doi:10.1016/s01681605(03)00083-7

37. Darmadji P, Izumimoto M. Effect of chitosan in meat preservation. Meat Sci. 1994;38(2):243-254. doi:10.1016/0309-1740(94)90114-7

38. Sanpui P, Murugadoss A, Prasad PV, Ghosh SS, Chattopadhyay A. The antibacterial properties of a novel chitosan-Ag-nanoparticle composite. Int J Food Microbiol. 2008;124(2):142-146. doi:10.1016/j. ijfoodmicro.2008.03.004

39. Bavand Z, Gholami S, Honary S, Rahimi Esboei B, Torabi $\mathrm{N}$, Barabadi $\mathrm{H}$. In vitro evaluation of the effect of gold nanoparticles on Giardia lamblia cyst. Arak Med Univ J. 2014;16(10). [Persian].

40. Wanule D, Balkhande JV, Ratnakar PU, Kulkarni AN, Bhowate CS. Extraction and FTIR analysis of chitosan from American cockroach, Periplaneta americana. International Journal of Engineering Science and Innovative Technology. 2014;3(3):299-304.

41. Kendra DF, Hadwiger LA. Characterization of the smallest chitosan oligomer that is maximally antifungal to Fusarium solani and elicits pisatin formation in Pisum sativum. Exp Mycol. 1984;8(3):276-281. doi:10.1016/01475975(84)90013-6

42. Alburquenque C, Bucarey SA, Neira-Carrillo A, Urzua B, Hermosilla G, Tapia CV. Antifungal activity of low molecular weight chitosan against clinical isolates of Candida spp. Med Mycol. 2010;48(8):1018-1023. doi:10.3 109/13693786.2010.486412 